\title{
Relendo o eterno feminino: figurações da mulher e do amor em A margem da alegria, de Ruy Belo
}

Isabella Batista de Souza Universidade Federal de Minas Gerais

Delicados são seus pés. Pois não é no chão que caminha, mas sobre as cabeças dos homens [...].

(Iliada, canto XIX)

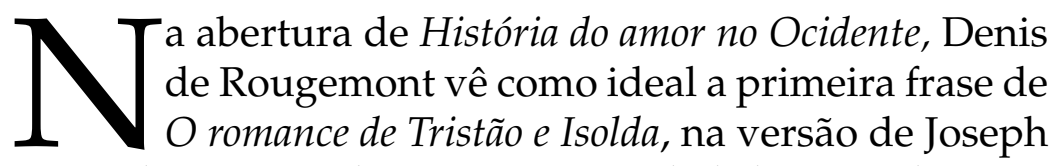
Bédier: "Senhores, agrada-vos ouvir uma bela história de amor e morte?..."1. O estudioso acredita ser Tristão e Isolda "o romance fundador do imaginário amoroso ocidental" ${ }^{2}$, ou seja, ele mostra que a origem do amor no ocidente se deu sob a égide do amorpaixão, que combina adultério, prazer e morte.

A margem da alegria, longo poema de Ruy Belo, também trata de uma "bela história de amor e morte". O par amoroso em questão é Inês de Castro e D. Pedro, filho do rei de Portugal. Pedro se apaixona por Inês de Castro, que vem de Castela a

\footnotetext{
${ }^{1}$ ROUGEMONT, 2003, p. 23.

${ }^{2}$ ROUGEMONT, 2003, p. 407.
} 
fim de servir como aia à sua esposa, Dona Constança. Inês é assassinada a mando do rei de Portugal, que teme pelo futuro do seu reino, já que a amante de seu filho é de origem espanhola.

O objetivo deste artigo é explorar as figurações da mulher e, por consequência, as do amor. Para tal, o texto se divide em duas seções principais, a primeira caracterizando as mulheres e a segunda abordando questões do amor implicadas ou não nas figuras femininas encontradas.

\section{Figurações femininas: as magníficas mulheres de $A$ margem da alegria}

Em A margem da alegria, a relevância das figuras femininas para a compreensão da obra e da poética de Ruy Belo se revela de diversas maneiras.

Primeiramente, a própria temática do livro, ao tratar da trágica história amorosa de Dom Pedro e Inês de Castro, coloca em destaque a mulher. Além de ser uma das figuras centrais da obra, Inês é também a figuração feminina por excelência paradigma da mulher em Ruy Belo.

Inês, base da construção feminina, aglutina-se às demais figuras femininas invocadas ao longo do poema para construir uma mulher, ao mesmo tempo, única e plural: a mulher literária criada pelo poeta. Ainda sobre a força de Inês de Castro na poesia de Ruy Belo, há em Toda a terra, livro publicado imediatamente depois de A margem da alegria, poemas que se baseiam em Inês para se referir a outra mulher. Isabel Freire, amada do poeta quinhentista Garcilaso de La Vega, é quem está referida nos títulos dos poemas, e somente nos títulos, porque os versos apontam para Inês: "Mas de Isabel nem uma única referência ao longo dos 131 versos deste texto. Desconcertantemente,não 
é Isabel, mas Inês, que o poema refere, num tratamento enunciativo que exigirá detença." ${ }^{3}$

O segundo ponto que indica essa importância da mulher na obra evidencia-se no próprio poema (grifo meu): "quando repito existiam as mulheres sempre elas as mulheres / sempre as mesmas as diferentes mulheres" ${ }^{\prime \prime}$. Nesse trecho, o sujeito se mostra no poema a fim de enfatizar algo que já vinha sendo dito e que não pode ser deixado de lado. O alerta é sobre a existência das mulheres e sobre suas figuras paradoxais. Essa aparição do sujeito lírico é legitimada pela necessidade de avisar os leitores de que a mulher é, de fato, um ponto crucial nessa obra.

Assim, o poder da mulher é constatado pelas próprias figurações, que transbordam por toda a obra. Para compreender o papel dessas figuras e suas ressonâncias com a ideia de amor, essa seção objetiva identificar e caracterizar algumas das inúmeras mulheres de $A$ margem da alegria. São várias as relações abordadas nesse trabalho que podem constituir a figura feminina: a mulher e os elementos da natureza; a mulher e a ideia de amor; a mulher a partir da reflexão sobre o cânone feminino das musas literárias.

Entretanto, antes de abordar a imagística da mulher em Ruy Belo, faz-se necessária uma reflexão teórica acerca da figura da mulher como lugar literário. A mulher da qual se fala é aquela marcada "pela letra e pela materialidade dos significantes, [que] é, principalmente, figura de linguagem e figura literária" A figura feminina à qual se reporta não é empírica, mas um conceito demarcado pela literatura e, consequentemente, pela linguagem.

Assim, não se trata de pensar o lugar político e social da mulher na literatura. A mulher focada nessa pesquisa é

\footnotetext{
${ }^{3}$ MORUJÃO, 2011, p. 72.

${ }^{4}$ BELO, 2009, p. 563.

${ }^{5}$ BRANDÃO, 2006, p. 29.
} 
conceitual; é, antes de tudo, matéria literária e, principalmente, matéria poética. Esse conceito comporta ideias que auxiliam em uma compreensão mais abrangente do poeta como construtor de linguagem. Ao se delinear, a imagem feminina surge, pouco a pouco, ligada a concepções mito-poéticas, podendo apontar, também, para a própria relação do poeta com a literatura.

Para se traçar os contornos da mulher beliana é importante frisar que essas marcações não são completamente definidas e estanques. Essa figura é tão múltipla quanto a própria linguagem poética: defini-la completamente seria não apenas um equívoco, como um ato redutor de uma complexa poesia como é a de Ruy Belo. Afinal, a própria natureza da poesia - e da arte, em geral - não permite análises petrificadas, improdutivas para a contínua compreensão da obra artística.

A figura da mulher na literatura nunca se apresenta estável, definitiva, e é nessa característica que reside sua fertilidade, como vemos a seguir:

Repete-se, incessantemente, a palavra enigma em relação à mulher, entretanto, vimos que, se enigma supõe uma resposta acabada a uma questão proposta, não é por essa via que se chega ao feminino, sempre rebelde às soluções definitivas. A resposta a um suposto enigma é outra armadilha de um não-saber que prolifera ou multiplica respostas, apontando, entretanto, para a vacuidade que é a ausência de um significante único.

Esse vazio, longe de apresentar uma qualidade negativa, é o lugar da produção de novas e poéticas metáforas, lugar do tesouro da poesia, possibilidade que se abre na linguagem de romper a barreira do recalcado. ${ }^{6}$

O ser feminino em $A$ margem da alegria, portanto, é um catalisador, que a partir de sua potência de sentido gera novas interações e possibilidades dentro da obra poética.

${ }^{6}$ BRANDÃO, 2006, p. 201. 


\section{Composição da mulher: elementos recorrentes}

Um dos elementos mais recorrentes na composição da imagem feminina é a água. Em quase todos os trechos nos quais se fala em mulher, fala-se, também, em água ou palavras similares, seja no nível semântico: mar, chuva, fonte, lágrimas; seja no nível formal: "e haja alguma água mesmo na palavra mágoa" 7. Logo na página de abertura de $A$ margem da alegria, podemos identificar a relação mulher-água:

quando as tardes eram notoriamente altas e as sulcavam vozes de muitas raparigas que voltavam das fontes ou de [minas com avencas

de bilhas muito esguias à cabeça bilhas que prolongavam [o seu porte

o seu andar seguro e digno bilhas de mãos fincadas nas [ilhargas

bilhas extremamente sabedoras desgastadas afinal pelo [convívio

com os limos com os seixos muito brancos e moldados pela [água

na época do ano em que a chuva restituíra à terra em forma [líquida

parte da água que há muito lhe devia e agora humedecia [coisas in-

significantes como os humílimos botões dos musgos ${ }^{8}$

A figura feminina está calcada em uma única cena: o ato de buscar água nas fontes. É a partir dela que o corpo da mulher ganha força e se forma, ao mesmo tempo em que coexiste com a natureza. A força está no coro de vozes das raparigas, capaz de abrir buracos na tarde, deformando o tempo. A forma se delineia em um corpo físico, com o vaso na cabeça e as mãos na cintura.

\footnotetext{
${ }^{7}$ BELO, 2009, p. 577.

${ }^{8}$ BELO, 2009, p. 555.
} 
É necessário atenção para a composição dessa figura: as bilhas (vasos bojudos para carregar água) na cabeça e as mãos fincadas na cintura. Ao se traçar o contorno desse corpo, encontra-se uma imagem ondulada, esguia e altiva. O contorno do bojo do vaso, o contorno dos braços e o restante do corpo feminino seguem um fluxo de curvas que se assemelha às próprias bilhas. Desse modo, não há separação entre vaso e mulher, já que ambos são moldados em um único corpo. O corpo da mulher alcança, com a linguagem poética, a plasticidade de uma escultura.

É nessa junção, mulher e bilha, que os vasos, elementos portadores da água, adquirem vida. Ao se complementarem na mulher, eles absorvem características que são dela também (ou vice-versa): "extremamente sabedoras", "desgastadas pelo convívio".

Essa relação mulher-bilha, além de expressar uma forte ligação daquela figura com a água, também aponta para um tempo em que o ser humano vivia harmoniosamente na terra. No primeiro caso, vê-se que o ato de carregar água é algo tão habitual que resulta no "andar seguro" das raparigas. Essa simplicidade desse rito cotidiano pertence ao tempo destacado acima, no qual havia um equilíbrio na natureza que se mostrava até mesmo em coisas insignificantes, como "os humílimos botões dos musgos".

Outro elemento presente nos entornos da mulher é a árvore. Nos versos a seguir, o corpo feminino adquire forma a partir de metáforas como ciprestes (árvores similares aos pinheiros) e bouças de tojo ("bouça" sendo um terreno vedado onde se cria mato para adubo, por não ser próprio para a cultura, e "tojo", um arbusto de flores amarelas).

ou os cabelos das mulheres se prendiam nesta ou naquela [das mais altas bouças de tojo

que dão àquele que passa a impressão de terem visto o 
[verdadeiro amarelo

e as próprias mulheres recortadas no ar crepuscular como ciprestes muitas vezes mas talvez umas horas mais [tarde

quando perfuram decididamente a mais escura escuridão e temos o pressentimento de que alguma coisa vai por fim [acontecer ${ }^{9}$

Essas metáforas correspondem, respectivamente, ao corpo, figura recortada pelo ar crepuscular, e aos cabelos loiros de verdadeiro amarelo. Estes são moldados como uma bela imagem da natureza, que os assemelha a um canteiro repleto de flores, "que dão àquele que passa a impressão de terem visto o verdadeiro amarelo". Nesse verso, o olhar é mediador do sentimento causado naquele que vê a verdadeira beleza das mulheres com seus cabelos loiros. A força dessa figura feminina é transmitida por esses belos corpos. Além disso, o vocabulário também é responsável pelo poder dessa beleza ao relacionar às figuras femininas palavras fortes como perfurar e recortadas.

Sobre o corpo, observa-se que, ao ser recortado pelo final do dia, ele se distingue do restante do cenário. Nesse momento crepuscular, assume os contornos definidos dos ciprestes, assimilando uma postura estática. Porém, com a chegada da noite, a mulher ganha movimento e força, é o momento em que "alguma coisa vai por fim acontecer" - essa mudança de estático para móvel também é indiciada pela conjunção adversativa mas. Portanto, a escuridão não é um empecilho para a mulher, pelo contrário, é uma condição que lhe possibilita agir.

Há, pois, uma mulher que se esboça através de uma íntima relação com a natureza, principalmente a partir da água e das árvores; através de uma beleza tão verdadeira que atinge com violência aquele que almeja vê-la; e através de uma ligação com

${ }^{9}$ BELO, 2009, p. 560. 
a noite, que pode ser, até mesmo, dela dependente. Portanto, eis a primeira imagem esboçada e que deve ser reservada para futuras análises: um ser belo, noturno, ligado à natureza.

\section{Inês ou a mulher ideal}

A próxima figura de mulher é Inês de Castro, principal referência em $A$ margem da alegria, e, portanto, indispensável para a compreensão da obra e da personagem feminina.

A amante de Pedro é uma figura recorrente na literatura portuguesa. Saliente-se o fato de que Inês foi eternizada pela literatura, responsável por transformá-la de mera personagem histórica em personagem mítica: “Em Portugal, porém, é com as Trovas de Garcia de Resende, publicadas em 1516, que Inês e Pedro se tornam definitivamente personagens míticos, ultrapassando de longe a sua restrita dimensão histórica." ${ }^{10}$. Até mesmo na obra de Ruy Belo essa indicação está presente: "lembrada só depois nas trovas de garcia de resende" ${ }^{11}$. Logo, a mulher eleita como paradigma tem sua força e, de certa forma, sua origem no próprio texto literário.

Há dois momentos que se diferenciam mais nitidamente no que diz respeito à caracterização de Inês. No início de $A$ Margem da Alegria, a personagem aparece relacionada com elementos materiais, datas históricas e fatos, ora verdadeiros, ora presentes no imaginário popular português. Essa Inês é inofensiva, estática e composta por características já bastante conhecidas. Já nas partes mais avançadas do poema, formase uma mulher instável, muitas vezes paradoxal, ofensiva e, sobretudo, etérea. Nesse momento, não só Inês é cada vez mais abstrata como a intensidade do poema aumenta, adquirindo outro nível de complexidade.

\footnotetext{
${ }^{10}$ MARINHO, 1990, p. 104.

${ }^{11}$ BELO, 2009, p. 568.
} 
Vê-se, abaixo, uma descrição detalhada do túmulo de Inês, no mosteiro de Santa Maria de Alcobaça, onde, também, está o corpo de Dom Pedro. Os desenhos laterais (gabletes ou paredes ornamentais triangulares do túmulo) e os ornamentos no entorno (cães e anjos com incensórios) são exatamente como os descritos:

Nas faces laterais dos dois duplos frontais há vinte e quatro mais gabletes cardinados e aos pés de cada um dos dois há cinco cães fiéis a aos lados dois pares de anjos com turíbulos e com navetas a incensar os corpos insensatos dos amantes adornados de mantos e coroas reais e a rosácea tumular tem afinal aquela rudeza do real mais que a simbólica ou moral pois a rainha morta nunca usou coroa real ${ }^{12}$

Indica-se, assim, uma materialidade que aponta sempre para a morte. Isso é observado em trechos como: "no túmulo deitada inês parece a própria placidez"13; "inês mais pedra que osso"14; e "inês morta inês sepulta"15.

Já os últimos versos se referem à rosácea e à coroa, que estão situadas sob a cabeça da estátua de Inês esculpida no túmulo. Nesses dois símbolos, encontra-se a rudeza do real, já que ela só foi reconhecida como rainha após sua morte - o próprio Pedro negou ter se casado escondido com Inês, mas depois a reconheceu como sua esposa. Por isso é chamada de rainha morta, designação bastante utilizada para Inês. É especificamente por essa condição que, nessa parte da obra, Inês é um ser estático, pétreo, preso a seu destino trágico.

\footnotetext{
${ }^{12}$ BELO, 2009, p. 567.

${ }^{13}$ BELO, 2009, p. 564.

${ }^{14}$ BELO, 2009, p. 565.

${ }^{15}$ BELO, 2009, p. 570.
} 
Os trechos selecionados nesse primeiro momento pertencem à terceira divisão do poema, que conta detalhadamente a história de Pedro e Inês, utilizando desde a precisão das datas históricas até as cenas incertas que povoam o imaginário coletivo sobre Inês. A distinção entre verdade e imaginação não interessa nessa obra, pelo contrário, ambas têm o mesmo valor. Uma complementa a outra, enriquecendo o poder mitológico da figura de Inês de Castro.

Esse primeiro momento explora aquilo que se sabe sobre "aquela que depois de morta foi rainha", uma mistura de fatos históricos com incertezas oriundas do universo popular relativo a essa figura:

inês colo de garça designada
bem cedo desterrada para o burgo de Albuquerque
castelo fronteiriço donde após morta constança
pedro contra seu pai fez regressar
e receber em casa para começar com ela
a fazer afrontosa maridança
e um feroz amor somente terminado
em quarta-feira dia sete de janeiro
do ano do senhor de mil trezentos e cinquenta e cinco
no passo derradeiro naquele paço da rainha
logo que degolado o alto e alvo colo
só por razões de estado [... $]^{16}$

Nesses versos, vê-se a tentativa do príncipe de se casar com Inês após a morte da sua esposa Constança. Porém por razões de estado, Inês, originária de Castela, foi assassinada, degolada, na data de sete de janeiro de 1355, como está indicado por extenso no poema. Identifica-se, também, outra expressão comum para Inês, "colo de garça". O poeta aproveita o codinome para

${ }^{16}$ BELO, 2009, p. 568-569. 
dar forma de ave a Inês e, inversamente, para transformar os pássaros em Inês.

Percebe-se, então, que Ruy Belo dá nova cara aos elementos do universo inesiano com sua linguagem poética característica. Porém, o traço mais relevante é que, nesse primeiro momento, a figura de Inês de Castro não é excedida. Trata-se somente da história de amor de Pedro e Inês - Inês que é Inês.

Em um segundo momento, essa mulher avança de Inês de Castro para Inês, ideal da mulher beliana. Esse processo se dá através da configuração de novas características ligadas a essa figura feminina, como veremos a seguir. Ela se torna instável: "E assim inês confia e desconfia / confia na alegria e teme de tristeza / e tem falas contrárias mais do que a contradição"17. Ela se torna dominadora, manipuladora do poder do amor que faz o outro sofrer: "Inês detém a fala da mulher humana / e se alguém se apaixona logo ela o domina / e aprende a chorar quem só sabia rir / e torna-se terrível quem sempre era amável / e pensativo mesmo um ânimo expansivo"18.

A ascensão de Inês, de real para ideal, evidencia-se à medida que o livro avança:

Inês morta uma vez só por amar talvez vive em seu nome pois o não consome o tempo que afinal encerra tudo nesta terra pois teve por destino ser o eterno feminino à feminilidade conferir a individualidade e mais do que real ser ideal ${ }^{19}$

$\mathrm{O}$ amor, aqui, resulta em duas consequências: morte e imortalidade. Foi por amar que Inês morreu, mas também

${ }^{17}$ BELO, 2009, p. 588.

${ }^{18}$ BELO, 2009, p. 591.

${ }^{19}$ BELO, 2009, p. 606. 
foi por amar que ela se imortalizou, sendo considerada em $A$ margem da alegria como figuração do eterno feminino. Inês vive e perdura através de seu nome, que se instituiu de tal forma que é capaz de conotar signos particulares a ele. Além disso, Inês pode ser tratada como uma espécie de figuração do eterno feminino porque é o protótipo da mulher ideal, segundo a concepção de Ruy Belo.

Assim ela também o é como ideal de beleza: "Não tornou algum deus inês ditosa ao fazê-la formosa / talvez tivesse sido o mar que abriu terá sido de lá que ela saiu / antes que boticelli a fizesse nascer / sair das águas essa deusa que jamais havia / de deixar de reinar e de todos vencer ${ }^{\prime 20}$. A clara referência ao quadro de Botticelli, O nascimento de Vênus, expressa como Inês é relacionada, no poema em pauta, com a beleza e o amor. Ela é equiparada à deusa greco-romana do amor e da beleza, reforçando seu caráter de eterno feminino.

Logo, os dois momentos de Inês caracterizam uma segunda imagem feminina: a da mulher como ideal. Inês ascende de um corpo belo para a própria Beleza (do material para o abstrato, para a ideia). Agora, Inês é Mulher. Por isso, mais prolífica: por ser Mulher, Inês contém todas as outras, multiplicando as possibilidades da figuração feminina.

Mulher ideal é também aquela da tradição do amor cortês, da qual Inês também faz parte:

mulher que para sempre jaz no espírito cortês de quem sempre a corteja embora pouco a veja e a não deseja com um desejo que ultraja e a não quer destruir só por um dia a possuir pois sabe que perdeu todas as que ele possuiu mulher madona de ar de quem domina mulher um dia minha mesmo se ela o adivinha

${ }^{20}$ BELO, 2009, p. 604. 
e tem tão brancos dentes que jamais eu antes vira uma vez sequer num rosto de mulher e tem na pele a alvura da luz que inaugura o dia ou a alegria onde uma vida principia e ao começar termina a luz com que ilumina e tem essa grácil cabeça onde o amor começa e onde se constrói o que dentro de pouco se destrói ${ }^{21}$

Têm-se duas relações distintas: uma sobre o tratamento da mulher segundo o amor cortês e outra sobre as características de um rosto feminino (os dentes, a pele, a cabeça). Embora se delineie como uma metonímia do corpo, esse último é moldado a partir de elementos abstratos. Os dentes são de uma brancura inexistente em outras mulheres e a pele é como a luz - que irradia não só o dia, mas a alegria e a vida. Essa mulher também dá origem ao amor, sendo ela responsável por construí-lo e destruí-lo. Ela dá vida, mas também mata.

Na primeira relação é interessante ver que as características do amor cortês significam a não destruição da mulher: cortejar a mulher e desejá-la sem ultrajá-la fazem parte do ritual do amor cortês, mas significam aqui o existir contínuo da figura feminina. $\mathrm{O}$ tratamento conferido à mulher é o que faz com que ela perdure, é o que faz com que exista a possibilidade, para o sujeito lírico, de tê-la e, mais importante, a certeza de não perdê-la.

Delineou-se, então, outra Inês, que é também Ideal, mas como sinônimo do amor-cortês. Porém, o amor-cortês surge como modo de preservação da mulher. É por seguir as regras dessa tradição que o sujeito não perde a Mulher.

Na verdade, toda a obra sofre uma alteração significativa, que tem origem na relação sujeito-lírico-mulher e fica mais presente à medida que a obra avança. Isso fica evidente no ritmo,

${ }^{21}$ BELO, 2009, p. 595. 
cada vez mais intenso, com uma abundância de aliterações e assonâncias, e também no conteúdo, já que se trata menos de Inês e Pedro e mais daquilo que eles potencialmente são capazes de encenar como figuras literárias e par amoroso.

Não se sabe exatamente quem é esse sujeito-lírico. Sabe-se que ele é múltiplo: às vezes é Pedro, às vezes é somente sujeitolírico e, ainda, pode ser Pedro como sujeito-lírico (poeta pedro). Isso acontece porque ele é enquadrado no tempo do homem contemporâneo, mas se identifica com um tempo já passado:

quando as pessoas já eram mortais mas não o eram assim excessivamente

e se reconheciam a si próprias nuns olhos alheios

e a sua pele humedecia e se tornava cada vez mais fina sem deixar de ser pele sem passar a ser cútis a não ser nos anúncios ou nos salões de cabeleireiras onde sempre se fala só dos outros da vida privada dos outros dos pequenos escândalos diários ${ }^{22}$

O trecho abaixo exemplifica algumas das questões comentadas acima (como a condição do sujeito-lírico) e coloca algumas questões:

inês diz o poeta ou pedro ou poeta pedro diz

não me dês numes dá-me apenas nomes

ou coisas sensuais e não sensíveis como os animais

talvez tão minerais como esse olhar que ao vê-lo não

[esquecemos mais

$[\ldots]$

Nasço subitamente há mundos no teu rosto

antes de ti ninguém na verdade houve

chove posso dizer pela primeira vez que chove

Esperar por ti não é esperar por ti

esperar por ti é ter talvez esperança

${ }^{22}$ BELO, 2009, p. 556. 
ou é esperar com minudenciosa paciência

e desenhar teu rosto em cada rosto que vejo surgir na minha alvoroçada vizinhança dos teus passos Ver-te é como ter à minha frente todo o tempo é tudo serem para mim estradas largas estradas onde passa o sol poente é o tempo parar e eu próprio duvidar mas sem pensar se o tempo existe existiu alguma vez e nem mesmo meço a devastação do meu passado [...]

ver-te é nem mesmo pensar que deixarei de ver-te ver-te é sentir pousar mais que um olhar uma mão muito calma sobre a minha vida ver o teu rosto é ter toda a certeza de que existo que sempre existirei que não há mais ninguém ver o teu rosto é mesmo mais do que nascer empreender viagens começadas nesse rosto donde podem sair inúmeros navios ver o teu rosto é como tudo começar [...]

Quando te vais embora fico de repente ao abandono sem ao menos a protecção de uns olhos de animal da copa arredondada de uma árvore Vais-te embora e deixa de haver árvores no mundo e não tenho palavras e não tenho voz $^{23}$

O longo trecho se pauta, basicamente, pela questão do olhar. A utilização anafórica de ver-te ou ver e a referência ao olhar de Inês como inesquecível apontam para algumas características do amor cortês. No ensaio "Olhos e coração na lírica galego-portuguesa", Yara Frateschi Vieira desenvolve as enumerações de Ruth Cline referentes ao amor cortês. Dentre as cinco proposições relativas ao amor cortês, três, a nosso ver, ajudam a compreender a poesia de Ruy Belo. São elas:

${ }^{23}$ BELO, 2009, p. 595-597. 
1. O amor é súbito e poderoso e ocorre geralmente com o primeiro olhar.

2. Os olhos são não apenas preceptores da beleza, mas também agentes, ao promoverem o amor.

3. Enquanto agentes, os olhos funcionam como uma arma que ataca, através dos olhos da amada, dentro do coração. ${ }^{24}$

Ver a mulher idealizada acalma o desassossego de uma vida com passado devastado. Vê-la garante ao sujeito lírico sua existência. Por vê-la é que ele adquire a consciência de si. Essa mulher se mostra tão abstrata quanto uma ideia: ela possui mundos no rosto, torna o tempo atemporal, possibilita navegações. Além disso, ela está fortemente ligada às árvores sem a mulher a proteção das árvores ao eu-lírico não se realiza. Há, portanto, uma dependência dessa mulher e, principalmente, das ideias que ganham fulgor através dessa figura feminina.

Assim, nesse segundo momento trata-se menos de Inês e Pedro e mais de como eles se tornam paradigma do amor - tal como Tristão e Isolda. A mulher desenhada nesta seção é tanto Inês de Castro como Mulher e Ideia. Ela está ligada à morte e a figurações do universo inesiano. Está ligada à Beleza e à violência dominadora do amor. E mais, ela é lembrada e preservada através da relação sujeito-mulher do amor cortês.

\section{Wanda: ecos de Sacher-Masoch em A margem da alegria}

Wanda, personagem célebre do escritor austríaco SacherMasoch, é uma das mais importantes citações presentes no poema de Ruy Belo. A heroína de A vênus das peles é a mulher

${ }^{24}$ VIEIRA, 2009, p. 12. 
pela qual o protagonista, Severin, apaixona-se e, também, aquela que o faz escravo. Em $A$ margem da alegria, podemos identificar a referência a este autor no seguinte trecho (grifo meu):

onde as donzelas ingressavam em silêncios tão cingidos [como certas árvores

nalguns finais de tardes com o sol envolto já em nuvens sobre a terra indecisa agressiva porém nos seus perfumes [penetrantes

à hora em que magníficas mulheres como a de sacher-masoch [põem pentes nos cabelos

e variegados tons ostentam os seus rostos sob os ramos mais derramados dos chorões mas prontas a romper em pranto ao simples canto de uma ave talvez oculta numa umbrosa laranjeira de dezembro ${ }^{25}$

Para um leitor não iniciado em Ruy Belo, o nome de Sacher-Masoch poderia passar despercebido, já que o desejo do poeta é que "palavra alguma levante a cabeça no meio da frase, por mais carregada de sagrado que a história no-la tenha feito chegar" ${ }^{\prime 26}$ - característica inovadora de sua poesia.

Na passagem acima, a mulher é delineada a partir de duas metáforas principais, a das árvores, associação bastante frequente em Ruy Belo, e a de Wanda, símbolo de beleza e crueldade. Já os dois últimos versos apontam para Inês (o canto da ave e a laranjeira são elementos comumente associados a ela).

As magnificas mulheres de $A$ margem da alegria são como a personagem de $A$ vênus das peles, Wanda. Ela é acompanhada de descrições fabulosas que mostram sua beleza, bem como seu poder exercido sobre Severin:

\footnotetext{
${ }^{25}$ BELO, 2009, p. 557.

${ }^{26}$ BELO, 2009, p. 18-19.
} 
Eu adentro. Ela está no meio do quarto, em um vestido acetinado branco, deixando-lhe entrar por baixo uma luz, e por cima dele uma kazabaika de cetim vermelho escarlate, debruado com um rico e suntuoso arminho. Nos cabelos empoados como que por uma neve, um pequeno diadema de brilhantes, os braços cruzados sobre o peito, as sobrancelhas franzidas. ${ }^{27}$

A referência a Wanda afirma, definitivamente, uma característica que vinha se firmando aos poucos: a violência. A mulher é agressiva, sua beleza é violenta. Não se trata de uma mulher apática, imóvel. É uma mulher ativa, e não inocente, participante de todo o processo, quer seja dominadora ou dominada.

O autor que deu nome ao masoquismo também se aproxima da concepção feminina de Ruy Belo por sua relação com o Ideal: "A empreitada pedagógica dos heróis de Masoch, a submissão à mulher, os tormentos que eles sofrem, a morte por que passam são momento de ascensão ao Ideal." ${ }^{28}$

Também é plausível equiparar os dois escritores no nível da linguagem. No poema de Belo, encontram-se diversos trechos que demonstram uma capacidade dialética de sua linguagem poética, em relação evidente com Camões: "Amor amor merece e não perece / aquele que o amor mata e transfigura / e transforma num servo quem era senhor / e faz do amador a coisa amada" ${ }^{29}$; ou "Pedro é mais do que tudo esse branco peito / ele amador é hoje a coisa amada / vive dentro de si a verdadeira vida / e consegue ser livre só por ser cativo" 30 ; e, ainda "É o cavalgador a coisa cavalgada / é a infância passada no presente pensada / até

\footnotetext{
${ }^{27}$ SACHER-MASOCH, 2008, p. 68.

${ }^{28}$ DELEUZE, 2009, p. 23.

${ }^{29}$ BELO, 2009, p. 605.

${ }^{30}$ BELO, 2009, p. 590.
} 
não ficar nada da nossa pegada / impressa sobre a areia desse país praia"31. Como no famoso soneto camoniano, o amador e a amada podem trocar de lugar, transformando-se um no outro: "amor de inês amor de pedro amor talvez/ que faz dois serem um de vez". 32

Também em Masoch, a mulher está envolvida com os deslocamentos dialéticos, definidos abaixo por Gilles Deleuze:

De outra maneira, o herói masoquista parece educado, formado pela mulher autoritária, porém mais profundamente é ele que a forma e a traveste, soprando-lhe também as palavras duras que deve dizer. [...] A dialética não significa simplesmente uma circulação do discurso, mas transferências e deslocamentos desse tipo, que fazem com que a mesma cena seja simultaneamente representada em diversos níveis, seguindo inversões e desdobramentos na distribuição dos papéis e da linguagem. ${ }^{33}$

Embora haja proximidades com Camões, a mulher em Ruy Belo é distinta da camoniana precisamente por exercer a violência. Em Os lusíadas, Inês é "ua fraca dama delicada" ${ }^{34} \mathrm{ou}$, ainda, "ua donzela, / Fraca e sem força" que se entrega à morte: "Mas ela, os olhos, com que o ar serena / (Bem como paciente e mansa ovelha) / Na mísera mãe postos, que endoudece, / Ao duro sacrifício se oferece." 35 . Já em Ruy Belo, Inês não é somente vítima, é também algoz: "Inês detém a fala da mulher humana / e se alguém se apaixona logo ela o domina / e aprende a chorar

${ }^{31}$ BELO, 2009, p. 599.

32 BELO, 2009, p. 591.

${ }^{33}$ DELEUZE, 2009, p. 25.

${ }^{34}$ CAMÕES, 1990, p. 144.

${ }^{35}$ CAMÕES, 1990, p. 146. 
quem só sabia rir / e torna-se terrível quem sempre era amável / e pensativo mesmo um ânimo expansivo" ${ }^{\prime \prime 36}$.

Pode-se perceber, então, a aproximação da mulher beliana com a mulher masoquista no sentido da violência, da linguagem dialética e das tentativas de ascensão ao Ideal.

No desenrolar de A margem da alegria é possível identificar diversas referências literárias, diretas e indiretas, formadoras de um cânone feminino e amoroso. Dentre as variadas figurações da mulher podemos destacar as musas literárias paradigmáticas do amor trágico, um amor que resulta em desastre e sofrimento: Marie Dorval ("flor lacrimosa flor tão triste e tão terrível / como a que vigny desenha no primeiro soneto a mariedorval"), Hélène de Surgères, Charlotte de Hardenberg ("se porventura perturbaste um pouco a minha vida / não te aflijas por isso hélène de surgères ou charlotte hardenberg" ${ }^{\prime 37}$ ) e Laura, de Petrarca.

Todas essas figuras têm como base a figura mitológica de Egéria (ou Égira), ninfa mitológica conselheira do rei romano Numa Pompílio. Segundo Ovídio, quando o rei de Roma morreu, a ninfa chorou tanto que se transformou em uma fonte.

Quando um dia soube da morte de numa égira começou a contorcer-se a sacudir os ramos a morrer e a sofrer por não saber a forma humana de chorar égira árvore égira fonte fonte para sempre fonte de cujas águas podem emergir nereidas a chorar para sempre a morte desse nebuloso rei égira símbolo da mulher que ama com amor símbolo de laura laura sem apelidos laura apenas laura possivelmente sem um nome sem sequer ter coisa alguma por trás Amor que faz falar mesmo o silêncio

\footnotetext{
${ }^{36}$ BELO, 2009, p. 591.

${ }^{37}$ BELO, 2009, p. 578.
} 
que abra na manhã um espaço para o sol

égira talvez esse loureiro talvez laura ${ }^{38}$

Laura, que é tanto aura (l'aura) quanto vento: o nome da amada de Petrarca significa vento, em italiano (sentido desdobrado por ele).

Há, ainda, a presença de uma figura feminina bem definida: Diana, a deusa da caça e dos animais selvagens: "quando as árvores de ariccia protegiam ainda os sacerdotes de diana /e as pátrias não eram como agora o sítio onde se morre" ${ }^{39}$

Assim, vê-se, mais uma vez, a ligação da figura feminina com a natureza - água e árvores, principalmente. A mulher emerge sob o signo literário.

\section{A mulher em Ruy Belo}

As diversas mulheres identificadas e caracterizadas ao longo da primeira seção podem ser divididas em três grupos distintos, tendo como base ideias relacionadas a elas, juntamente com a adição de outros elementos relevantes. $\mathrm{O}$ primeiro grupo reúne as mulheres ligadas à Beleza, ao Ideal e à Dialética. O segundo enquadra os elementos que vinculam a mulher à natureza, à noite e às aves. $\mathrm{O}$ último discute $\mathrm{a}$ significação das referências literárias e, portanto, relaciona-se com todos os outros.

Como já indicado, a mulher em $A$ margem da alegria traça um rota de ascensão que vai do corpóreo/ material ao abstrato, ou, como pressupõe o platonismo, ao mundo das ideias. A observação de José Américo Motta Pessanha ao estudar $O$

\footnotetext{
${ }^{38}$ BELO, 2009, p. 577.

${ }^{39}$ BELO, 2009, p. 559.
} 
banquete pode ser aproveitada para pensar a poesia de Ruy Belo: “De um belo corpo para todos os corpos belos - da singularidade à totalidade, ainda no plano empírico - o Amor vai conduzindo à incorporeidade do belo em si, à ideia, forma ou essência de Beleza." 40

Tem-se uma Inês "empírica", capaz de conduzir à ideia de Mulher e à ideia de Amor. Esse é o cerne da questão platônica de A margem da alegria: Pedro e Inês evoluem da sua significação ligada ao real (quem de fato foram) para a ideia de Amor, chegando ao Amor em si.

O amor platônico, que condiz com o amor beliano, é comentado por Pessanha:

Para Platão, como mostra Joly, é este último sentido [alante oposto a alado] que é o sentido filosófico de Eros. Escreve: “O amor platônico é, com efeito, o amor mitológico, mas filosoficamente revisto e corrigido. (...) Ele é menos o que voa do que o que faz voar". Falante e alante, o amor é impulso ascensional, do sentimento e da fala. Conduz do condicionado ao condicionante, do corpóreo ao incorpóreo. Tende ao absoluto: (re)conduz a alma do contingente e do efêmero ao essencial e ao eterno. ${ }^{41}$

O amor é agente, conduz ao eterno - por isso a morte é, por excelência, a condição do amor, em Ruy Belo. É através da morte que Inês se imortaliza. A última parte do poema demonstra a relevância desse momento: na décima divisão é retratado o cortejo fúnebre que translada o corpo de Inês da igreja de Santa Clara para o mosteiro de Santa Maria de Alcobaça. Além disso, a introdução cada vez mais intensa e frequente do sujeito lírico no texto, como analisado anteriormente, também é um indicativo de que o que importa é o amor em si, o belo em si.

\footnotetext{
${ }^{40}$ PESSANHA, 2009, p. 107.

${ }^{41}$ PESSANHA, 2009, p. 94.
} 
A dialética, como vista na subseção dedicada a Wanda, também fundamenta as ideias difundidas por Platão. O próprio processo do conhecimento acontece dialeticamente, para se passar do mundo sensível (opinião ou doxa) para o mundo inteligível (ciência ou episteme): "Cada fase encontra sua fundamentação e resolução na fase seguinte. O que não é visto claramente no plano sensível (e só pode ser objeto de conjetura) transforma-se em objeto de crença quando se tem condição de percepção nítida." 42

\section{Amor-paixão, amor cortês}

É impossível não lembrar de Tristão e Isolda ao ler $A$ margem da alegria. Ambas são histórias construídas sob o signo do amor-paixão: uma combinação de adultério, sofrimento, prazer e morte. A história de Pedro e Inês se enquadra na tradição ocidental amorosa:

Amor e morte, amor mortal: se isso não é toda a poesia, é, ao menos, tudo que há de popular, tudo o que há de universalmente emotivo em nossas literaturas; em nossas mais antigas lendas e em nossas mais belas canções. $\mathrm{O}$ amor feliz não tem história. Só existem romances do amor mortal, ou seja, do amor ameaçado e condenado pela própria vida. O que o lirismo ocidental exalta não é o prazer dos sentidos nem a paz fecunda do par amoroso. É menos o amor realizado do que a paixão de amor. E paixão significa sofrimento. Eis o fato fundamental. ${ }^{43}$

São vários os elementos femininos identificados na obra de Ruy Belo que se assemelham ao mito de Tristão - a natureza,

42 PESSANHA, 1991, p. XX.

${ }^{43}$ ROUGEMONT, 2003, p. 24. 
a noite, os pássaros. Este último elemento, particularmente, possui um papel importante em $O$ romance de Tristão e Isolda e, de modo geral, na literatura medieval de tradição cortês: "A erótica medieval também se fez simbolizar pelo bestiário. Elegeu determinados animais como emblemas inseparáveis do homem [...]. Ao apaixonado, forneceu a imagem do rouxinol." 44 No romance, o rouxinol é Tristão, que, escondido na floresta, encanta a noite com seu canto dedicado a Isolda:

Isolda escutava a voz sonora que vinha encantar a noite, $\mathrm{e}$ a voz elevava-se em queixume, de tal modo que não existe coração cruel, coração de assassino, que ela não enternecesse. A rainha pensou: "Donde vem essa melodia?..." De súbito ela compreendeu: “Ah, É Tristão! Assim, na floresta do Morois, ele imitava para meu encantamento os pássaros cantores. Ele parte, e este é o seu último adeus. Como lamenta-se! Tal como o rouxinol quando despede-se, no fim do verão, com grande tristeza. Amigo, nunca mais ouvirei tua voz!"45

Em Ruy Belo o rouxinol também é referenciado diversas vezes: "quando as lágrimas não eram nesse tempo densas e fechadas como pedras / nem deixavam nos rostos indeléveis como de certo modo deixam no trilho do seu canto os rouxinóis"46; "o silêncio do sol oposto ao rouxinol"47; "os rouxinóis cantavam como estrelas eles que / são sempre tão incompatíveis com o dia" 48 .

A natureza e a noite são o local e o momento de proteção dos amantes. É na floresta que Tristão e Isolda se escondem

\footnotetext{
${ }^{44}$ ALVES, 1999, p. 409.

${ }^{45}$ BÉDIER, 1988, p. 92.

${ }^{46}$ BELO, 2009, p. 560.

${ }^{47}$ BELO, 2009, p. 576.

${ }^{48}$ BELO, 2009, p. 610 e 611.
} 
quando fogem do castelo e é à noite que, com o cantar do rouxinol, os amantes se reencontram quando estão separados.

A morte também tem uma forte relação com o amor conforme era pensado no período medieval:

É na senda do mito difundido pelos poetas provençais, mito elaborado por opostos valores, qual bicéfala cabeça de Jano, que se desenvolve o amor na literatura portuguesa, apresentando ora uma face luminosa, espiritualizada pelas convenções de cortesia ou religiosidade, em que o amor conduz à morte, hipótese única de supremo êxtase, ora uma face sombria, presa sem possibilidade de remissão ao barro de que é feita a carne humana, barro germinal das delícias paradisíacas da queda, deleite da concupiscência do saber que só na experiência se extasia. ${ }^{49}$

É perceptível que a obra de Ruy Belo se identifica com os valores apresentados acima. É na morte que se realiza o ato amoroso: "Na tua carne podre enterro o bico como um corvo / cubro o teu corpo morto não vás tu sentir o frio / Noite de núpcias é esta noite de morte".$^{50}$

Há também a presença da rosa, imagem que no século XII simbolizava o erotismo. Em Ruy Belo, ela figura, mais uma vez, a morte e, consequentemente, aquela que foi morta: "mulher que só os homens podem olhar adorar e mesmo venerar / e só pede ao amor esse momento em que uma flor / brilha e exulta e logo jaz sepulta". .51

A referência a figuras literárias tem a ver com o próprio labor do poeta: é preciso olhar para trás para renovar a emoção da linguagem literária. Institui-se, assim, uma memória literária

\footnotetext{
${ }^{49}$ ALVES, 1999, p. 410.

${ }^{50}$ BELO, 2009, p. 613.

${ }^{51}$ BELO, 2009, p. 599.
} 
que ocorre não só por meio das referências, mas também através das relações sujeito-mundo e sujeito-mulher, bem como das significações da morte:

Há quem caia no mar há quem tropece em deus mas eu tenho terra nas mãos na terra tenho mais que terra dos campos terra antiga terra onde há homens e tempo terra terra seja onde for tenho afinal um pouco portugal Dizem-me que morreste que fazer? Eu era pouco mais que certos gestos e já quase nenhuns têm sentido Sentia-me à vontade nesta vida e agora compreendes sinto-me perdido [...]

No teu pequeno rosto eu tinha quase tudo infância mar países certos livros ${ }^{52}$<smiles>[AlH2]</smiles>

É minha a noite entre coimbra e alcobaça é minha a estrada a noite a ave inês [...]

Ora diz-me lá tu que lá estiveste isso afinal da morte como é? Pedro para saber bailou até morrer as coisas mesmo mudas têm voz vem cá ouvir como falam as coisas a noite o vento o rio tudo fala Mas nada tem a voz que o silêncio tem conheço pouco mas conheço-a bem noite de inês e pedro ó minha noite Eu que há tanto vivo que sei eu da vida $?^{53}$

\footnotetext{
${ }^{52}$ BELO, 2009, p. 612.

${ }^{53}$ BELO, 2009, p. 614.
} 
Aqui, o sujeito-lírico tem uma íntima relação com a terra, e, antes de ser um sujeito literário, é um sujeito que se relaciona com o mundo: "[...] em A Margem da Alegria o sujeito poético quase assume a função de narrador de uma história alheia, embora servindo-se do diálogo entre Pedro e Inês para colocar e dar espessura a questões ontológicas que são visceralmente suas [... $]^{\prime \prime 54}$. Sendo assim, a morte é um assunto impossível de ser desviado, e é com a memória, que jamais esquece Inês, que ela se faz presente: "tenho-te na memória mais do que o país mais do que a vida" 55 ; é como se o sujeito da escrita pudesse coexistir ou perdurar em tempos diferentes, a fim de jamais olvidar sua amada.

Deste modo, a mulher delineada em A margem da alegria pode ser pensada segundo os ideais platônicos (Ideal, Bela e regida por movimentos dialéticos); é símbolo do amor-paixão e, consequentemente, do amor cortês; é, ainda, a possibilidade de respaldar a memória literária, renovando a literatura através dela mesma.

\section{Referências bibliográficas}

ALVES, Maria Theresa Abelha. O rouxinol e a rosa entre as coitas e as ledices do amor-paixão. In: DUARTE, Lélia Parreira et al (Org.). Para sempre em mim. Belo Horizonte: CESPUC, 1999. p. 407-417.

BÉDIER, Joseph. O romance de Tristão e Isolda. Trad. Luis Claudio de Castro e Costa. São Paulo: Martins Fontes, 2006.

BELO, Ruy. A margem da alegria. In: . Todos os poemas. Lisboa: Assírio \& Alvim, 2009. p. 555-619.

. Aquele grande rio Eufrates. In: . Todos os poemas. Lisboa: Assírio \& Alvim, 2009. p. 9-132.

\footnotetext{
${ }^{54}$ MORUJÃO, 2011, p. 72.

${ }^{55}$ BELO, 2009, p. 609.
} 
Toda a terra. In: Todos os poemas. Lisboa: Assírio \& Alvim, 2009. p. 627-811.

BRANDÃO, Ruth Silviano. Mulher ao pé da letra: a personagem feminina na literatura. Belo Horizonte: Editora UFMG, 2006.

CAMÕES, Luís de. Os lusíadas. Belo Horizonte: Itatiaia, 1990.

DELEUZE, Gilles. Sacher-Masoch: o frio e o cruel. Trad. Jorge Bastos. Rio de Janeiro: Zahar, 2009.

MARINHO, Maria de Fátima. Inês era outra a vez. Revista da Faculdade de Letras: Línguas e Literaturas, Porto: Faculdade de Letras, FLUP, v. 7, II série, p. 103-135, 1990.

MORUJÃO, Isabel. Mulher única, inúmera mulher: trajectória da identidade a próposito de Isabel Freire em Ruy Belo. Colóquio/Letras, Lisboa, n. 178, p. 72-79, dez. 2011.

PESSANHA, José Américo Motta. Platão: as várias faces do amor. In: NOVAES, Adauto (Org.). Os sentidos da paixão. São Paulo: Companhia das Letras, 2009. p. 83-114.

OVÍDIO. As metamorfoses. Trad. David Gomes Jardim Junior. Rio de Janeiro: Tecnoprint, 1983.

PLATÃO. Diálogos. Trad. José Cavalcante de Souza, Jorge Paleikat e João Cruz Costa. São Paulo: Nova Cultural, 1991.

ROUGEMONT, Denis de. História do amor no Ocidente. Trad. Paulo Brandi e Ethel Brandi Cachapuz. Rio de Janeiro: Ediouro, 2003.

SACHER-MASOCH. A vênus das peles. Trad. Saulo Krieger. São Paulo: Hedra, 2008.

VIEIRA, Yara Frateschi. Olhos e coração na lírica galego-portuguesa. Revista do Centro de Estudos Portugueses, Belo Horizonte: Faculdade de Letras, UFMG, v. 29, n. 42, p. 11-36, jul.-dez. 2009. 


\section{Resumo}

O artigo objetiva abordar as figurações da mulher e do amor em A margem da alegria, a partir das figuras femininas (tais como Inês de Castro, Isolda, Wanda, Laura) e dos elementos relacionados a elas. Para tal, o texto se forma por dois eixos: o primeiro explora a relevância e a caracterização das figuras femininas delineadas; o segundo explana as noções de amor imbricadas ou não nas imagens femininas do longo poema de Ruy Belo.

\section{Abstract}

This article aims to approach the figurations of women and love in A margem da alegria based on the female figures (such as Inês de Castro, Isolda, Wanda, Laura) as well as the elements related to them. For this purpose, the text is organized in two axis: the first one explores the relevance and characterization of female figures outlined; the second one explains the notions of love imbricated or not in the female images of Ruy Belo's long poem. 